\title{
Three Levels of Lateral Inhibition: A Space-Time Study of the Retina of the Tiger Salamander
}

\author{
Botond Roska, Erik Nemeth, Laszlo Orzo, and Frank S. Werblin \\ Division of Neurobiology, Department of Molecular and Cell Biology, University of California at Berkeley, Berkeley, \\ California 94720
}

The space-time patterns of activity generated across arrays of retinal neurons can provide a sensitive measurement of the effects of neural interactions underlying retinal activity. We measured the excitatory and inhibitory components associated with these patterns at each cellular level in the retina and further dissected inhibitory components pharmacologically. Using perforated and loose patch recording, we measured the voltages, currents, or spiking at 91 lateral positions covering $\sim 2 \mathrm{~mm}$ in response to a flashed $300-\mu \mathrm{m}$-wide bar. First, we showed how the effect of well known lateral inhibition at the outer retina, mediated by horizontal cells, evolved in time to compress the spatial representation of the stimulus bar at ON and OFF bipolar cell bodies as well as horizontal cells. Second, we showed, for the first time, how $\mathrm{GABA}_{\mathrm{C}}$ receptor mediated amacrine cell feedback to bipolar terminals compresses the spatial representation of the stimulus bar at ON bipolar terminals over time. Third, we showed that a third spatiotemporal compression exists at the ganglion cell layer that is mediated by feedforward amacrine cells via $\mathrm{GABA}_{\mathrm{A}}$ receptors. These three inhibitory mechanisms, via three different receptor types, appear to compensate for the effects of lateral diffusion of activity attributable to dendritic spread and electrical coupling between retinal neurons. As a consequence, the width of the final representation at the ganglion cell level approximates the dimensions of the original stimulus bar.

Key words: retina; inhibition; feedback; patch clamp; activity pattern; GABA
The first receptive field measurements from retinal ganglion cells (Barlow, 1953; Kuffler, 1953) showed that a central excitatory region was embedded in a larger, antagonistic surround, providing the first evidence of lateral inhibition in the retina. Lateral inhibitory components were found in initial bipolar cell recordings (Werblin and Dowling, 1969; Kaneko, 1970), suggesting that at least part of the antagonistic effects seen in ganglion cells were mediated at the outer retina, probably via horizontal cells. Inhibitory feedback to bipolar cells has also been measured (Feigenspan et al., 1993; Lukasiewicz et al., 1994; Dong and Werblin, 1998). This system appears to truncate activity in time, but its spatial effects remain unknown. Similarly, feedforward inhibition to ganglion cells has been measured (Werblin, 1972; Lukasiewicz and Werblin, 1990; Han et al., 1997; Cook and McReynolds, 1998; Lukasiewicz and Shields, 1998). The spatial extent of the feedforward inhibition has been described (Lukasiewicz and Werblin, 1990), but the effect of this inhibition on the spatial and temporal representation of stimuli at the ganglion cell layer remains to be determined.

In this study we measured the space-time patterns of activity as each retinal layer represented the activity of a flashed stimulus bar. We patch-recorded cellular activity at 91 different lateral positions with respect to the stimulus, similar to the measurements of Ratliff and Hartline (1959), but we followed the full time

\footnotetext{
Received Sept. 13, 1999; revised Nov. 10, 1999; accepted Dec. 10, 1999.

This work was supported by National Institutes of Health Grant EY00561. We thank Mark Bieda for helping with the cell-attached patch-clamp technique. We also thank Divya Chander and Greg Maguire for recommending the use of the fluorescent dye calcein.

Correspondence should be addressed to Dr. Frank Werblin, 145 LSA, University of California at Berkeley, Berkeley, CA 94720. E-mail: werblin@socrates. berkeley.edu.

Copyright (C) 2000 Society for Neuroscience $\quad 0270-6474 / 00 / 201941-11 \$ 15.00 / 0$
}

course of the responses. With perforated patch (Horn and Marty, 1988) and cell-attached recording (McLarnon, 1991; Diamond and Copenhagen, 1993), we recorded membrane voltage and spiking as well as excitatory and inhibitory patterns of activity. When all 91 recordings were "played back" synchronously, they generated rich spatiotemporal patterns representing the $300-\mu \mathrm{m}$ wide stimulus bar at each retinal layer.

First, we show how the effect of horizontal cell feedback compresses the spatial representation of the stimulus, with a similar time course, at all cellular layers receiving direct input from cones: the ON and OFF bipolar cells as well as the horizontal cells. Second, we show, for the first time, that feedback inhibition to bipolar cells via $\mathrm{GABA}_{\mathrm{C}}$ receptors does not only act locally to truncate activity in time (Dong and Werblin, 1998) but also conveys inhibition laterally to compress the spatial representation of the stimulus across an array of bipolar terminals. Third, we provide evidence that a feedforward inhibition at $\mathrm{GABA}_{\mathrm{A}}$ receptors in a subpopulation of ganglion cells sharpens the spiking output in both space and time.

These three lateral inhibitory systems, acting at different sites and via different receptors, appear to reduce the spread of stimulus representations across arrays of retinal cells caused by finite dendritic width and cell coupling so that the "neural image" at the ganglion cell level output still approximates the dimensions of the original stimulus.

\section{MATERIALS AND METHODS}

\section{Preparation}

Experiments were performed on larval tiger salamander slices at room temperature as described by Werblin (1978). The thickness of the slices was $200-300 \mu \mathrm{m}$. 


\section{Perforated patch-clamp recording}

Light-evoked currents and voltages were recorded with the perforated patch-clamp technique (Horn and Marty, 1988) using amphotericin (Rae et al., 1991). Patch pipettes were pulled from borosilicate glass tubes (TW120F-4; World Precision Instruments, Sarasota, FL) on a FlamingBrown micropipette puller (P-87; Sutter Instruments, Novato, CA). The pipette resistance was 5-10 $\mathrm{M} \Omega$ measured in the control bath solution. The voltage- and current-clamp recordings were performed with an Axopatch 200B patch-clamp amplifier (Axon Instruments, Foster City, CA). The signal was filtered at 1 or $5 \mathrm{kHz}$ and digitized at $1 \mathrm{kHz}$ (voltage-clamp mode) or $5 \mathrm{kHz}$ (current-clamp mode) by a DT2828 data acquisition board (Data Translation, Marlboro, MA) connected to a Pentium personal computer (PC). The recording software RED was developed by $\mathrm{M}$. Wang in our laboratory. The recorded data were analyzed under Mathematica 3.0 (Wolfram Research, Champaign, IL).

\section{Cell-attached recordings}

Spikes from ganglion cells were recorded with the cell-attached configuration of the patch-clamp technique as described previously (McLarnon, 1991; Diamond and Copenhagen, 1993, 1995). Briefly, a loose seal, $50-500 \mathrm{M} \Omega$, was obtained with pipettes with resistances of $2-5 \mathrm{M} \Omega$. The recorded currents under voltage clamp at $0 \mathrm{mV}$ are proportional to the first derivative of the membrane potential with respect to time (capacitive current) at the soma of the recorded ganglion cell. Each action potential is represented as a biphasic event in these recordings.

\section{Bath solution}

The control bath solution contained (in $\mathrm{mm}$ ): $108 \mathrm{NaCl}, 2.5 \mathrm{KCl}, 2$ $\mathrm{CaCl}_{2}, 1 \mathrm{MgCl}_{2}, 5$ HEPES, and 10 glucose. The $\mathrm{pH}$ was adjusted to 7.8 with $\mathrm{NaOH}$. The blockers were added to the control solution.

\section{Electrode solution}

The composition of the patch-electrode solution for cones, bipolar cells, amacrine cells, and ganglion cells was (in mM): $101 \mathrm{Kgluconate}, 8.5 \mathrm{KCl}$, $0.0078 \mathrm{CaCl}_{2}, 1 \mathrm{MgCl}_{2}, 0.1 \mathrm{BABTAK}_{4}, 10 \mathrm{HEPES}, 4 \mathrm{ATPNa}_{2}$, and 0.5 $\mathrm{GTPNa}_{3}$. The $\mathrm{pH}$ was adjusted to 7.4 with $\mathrm{KOH}$. The calculated $E_{\mathrm{Cl}}$ was $-60 \mathrm{mV}$.

The composition of the patch-electrode solution for horizontal cells was (in mM): $59 \mathrm{Kgluconate}, 46 \mathrm{KCl}, 0.5 \mathrm{CaCl}_{2}, 1 \mathrm{MgCl}_{2}, 1.3 \mathrm{BABTAK}_{4}$, $5 \mathrm{HEPES}, 4 \mathrm{ATPNa}{ }_{2}$, and $0.5 \mathrm{GTPNa}_{3}$. The $\mathrm{pH}$ was adjusted to 7.4 with $\mathrm{KOH}$. The calculated $E_{\mathrm{Cl}}$ was $-20 \mathrm{mV}$.

\section{Cell identification}

Cells were identified by their light response and morphology. To reveal morphology we added $0.5 \mathrm{mg} / \mathrm{ml}$ calcein (Molecular Probes, Eugene, OR) to our electrode solution. Calcein is a fluorescent molecule with emission spectra similar to that of Lucifer yellow. We used calcein instead of Lucifer yellow because calcein diffused through the amphotericin pores whereas Lucifer yellow was trapped in the electrode pipette. Calcein labeled brightly the measured cell bodies and processes. We found no evidence of dye coupling. The cells were viewed using a Nikon mercury fluorescent epi-illuminator (Nikon, Melville, NY) with an XF15 filter set (Omega Optical, Brattleboro, VT).

All drugs were purchased from Sigma (St. Louis, MO) unless otherwise indicated.

The solutions were changed by a gravity-driven perfusion setup with a $3-4 \mathrm{ml} / \mathrm{min}$ flow rate at room temperature.

\section{Light stimulus}

A color liquid crystal display (LCD) panel (Polaview 1700; Polaroid Corporation, Cambridge, MA) driven by a Pentium PC was used to project the stimulus images onto the retinal slice. The stimulus image was a 300- $\mu \mathrm{m}$-wide red bar flashed for $1 \mathrm{sec}$ on a green background. The intensity of the stimulus was $300 \mu \mathrm{W} / \mathrm{mm}^{2}$, and the intensity of the background was $13 \mu \mathrm{W} / \mathrm{mm}^{2}$ throughout all the recordings. The background intensity was raised to a level to saturate the rods ( $\mathrm{Vu}$ et al., 1997). The LCD panel was illuminated with a home-built variable intensity $(0-2000 \mathrm{~W})$ lamp. The intensity of the lamp was spatially homogenous over the area of the display panel. The image was reduced in size by two achromatic lenses (Edmund Scientific Co., Barrington, NJ) and was projected to the retinal slice through a Nikon condenser. The image path was changed by first surface mirrors and a beam splitter (Edmund Scientific Co.). The image parameters were controlled by the same software that controlled the data acquisition (RED; written by Monte Wang).

\section{Space-time pattern reconstruction}

According to the idea described in Results, the following procedure was used to measure the space-time patterns of activity at the different retinal layers: the $300-\mu \mathrm{m}$-wide red bar was flashed every $10 \mathrm{sec}$ in a linear array of 91 locations, separated by $20 \mu \mathrm{m}$ in a pseudorandom order. The response to each flash was recorded from a single cell at the center of the stimulus array, and at the end of the raster the responses were ordered according to their location and displayed simultaneously. To record excitatory current patterns, we voltage-clamped the perforated patch-clamped neuron at $-60 \mathrm{mV}$, the chloride reversal potential between the pipette and the bath solution. Under this condition no current flows through GABA- and glycine-gated chloride channels. Inhibitory current patterns were measured under voltage clamp at $0 \mathrm{mV}$, at the reversal potential of glutamate-gated excitatory currents. Membrane voltage patterns were recorded under current-clamp mode. Spiking patterns were recorded using the cell-attached recording technique (described above).

\section{Activity pattern parameters}

We used the following parameters to describe quantitatively the activity patterns in space and time.

Space constant. Each time frame was fit by a Gaussian function (except in the cone pattern): $A * \operatorname{Exp}\left[-B^{*}(x-C)^{2}\right] . A$ is the magnitude of the center response; $C$ is the location of the center. The space constant $(\lambda)$ in our study is defined by $(1 / B)^{0.5}$ minus one-half of the stimulus width, which was $150 \mu \mathrm{m}$. In the case of the cone pattern the Gaussian approximation was not a good fit. In this case we fitted the spatial profile with a simple exponential from both sides.

Time to peak. This parameter is defined at each location as the time needed to reach $90 \%$ of the peak response from stimulus ON.

Duration. Duration $\left(T_{50}\right)$ is the time it takes to increase from $50 \%$ of the peak to the peak and then to fall again to $50 \%$ of the peak during light $\mathrm{ON}$.

Sustained-to-peak ratio. The magnitude of the response at the end of the stimulus is divided by the magnitude of the peak response.

Charge transfer. This parameter is the integral of the current response during light $\mathrm{ON}$.

Width of the spike pattern at light $O N$ or OFF. This width is the maximum of the distances between the two most lateral spikes in the time frames during light $\mathrm{ON}$ or OFF.

Data are presented as the mean $\pm \mathrm{SD}$.

\section{RESULTS}

\section{Reconstructing patterns of activity at each retinal layer}

We measured patterns of membrane potential, excitatory currents, and inhibitory currents by recording from a single cell, and in a series of measurements, we moved the stimulus, a $300-\mu \mathrm{m}-$ wide bar, to 91 different positions separated by $20 \mu \mathrm{m}$ across the retinal slice. The recorded cell served as the representative of each of the cells of the same type across a row. When all of the recordings were played back simultaneously, synchronized with the stimulus flash and in proper spatial order, a spatiotemporal pattern of activity was generated that approximated the response of a row of cells across $1.8 \mathrm{~mm}$ of retina to a $300-\mu \mathrm{m}$-wide flashed bar. The pattern is only an approximation because this reconstruction technique fails to capture the temporal correlation between retinal neurons, and depending on the actual density of neurons, our approximated patterns can be spatially oversampled or undersampled. The scheme is illustrated for a 10-cell array in Figure 1.

Our goal was to reconstruct the excitatory, inhibitory, and membrane potential activity patterns at several retinal layers in response to the same 300- $\mu \mathrm{m}$-wide stimulus bar. By comparing the space-time characteristics of activity patterns at different retinal layers under different pharmacological conditions, we attempted to associate different cell types with specific functions. 


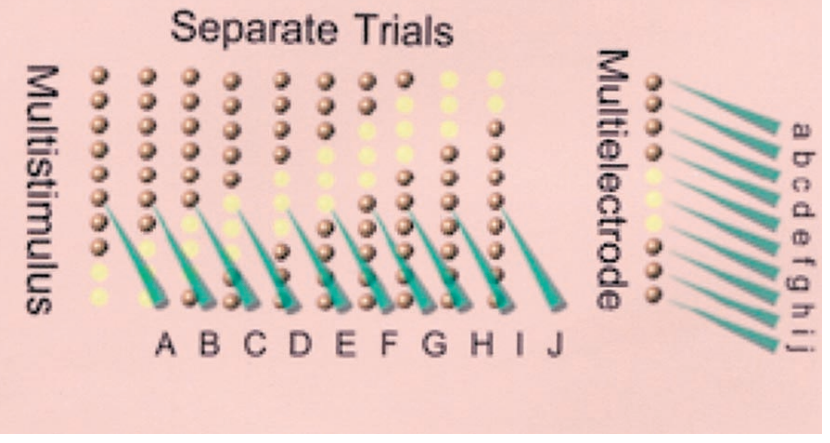

Figure 1. Generating retinal patterns. Right, The multielectrode array is shown. Pattern recording was with 10 patch electrodes. The complete pattern is generated by one flash. The stimulus bar is indicated by the band of lightly colored cells at the center of the array. Left, The multistimulus array recording requires 10 trials with a single electrode recording from a single cell. For each trial the stimulus is placed at one of 10 different locations. In the first trial, recording $A$ is in the same spatial relation to the stimulus as is recording $a$ from the multielectrode array. In the second trial, recording $B$ will be in a position corresponding to that of recording $b$, and so on. Recordings $F$ and $f$ are both taken at the center of the stimulus. When these 10 separate recordings are played back simultaneously, they generate a 10 line space-time pattern of cellular activity in space and time similar to that obtained from the single trial in the multielectrode array.

The Results section describes the activity patterns at the different layers in anatomical order, from cones to ganglion cells. This allows one to read through the figures and follow activity patterns in the order they are activated in the retina (see Fig. 2 for a simple circuitry).

The cone activity pattern serves as an essential control measurement for the rest of the results presented in this paper. The dynamics and spatial dimensions of the cone activity pattern define the dimensions of the neural input to the more proximal retinal layers. Comparing the activity patterns of the more proximal cells with that of the cone rather than the stimulus allows us to control for a possible blur of the stimulus projected onto the retina.

\section{The cone layer activity pattern defines the neural input to the retina}

A representative space-time pattern of membrane voltage at the cone layer, evoked by a 300- $\mu \mathrm{m}$-wide bar, is shown in Figure $3 A$. The spatial extent of the response pattern closely matched the spatial extent of the stimulus. The space constant was $33 \pm 8 \mu \mathrm{m}$ $(n=4)$ at the peak of the response after stimulus ON and remained constant (Fig. 3B) during the presence of the stimulus. The measured, small space constant is consistent with the measurements of Attwell et al. (1984). The narrow spatial distribution of the cone voltages at the peak and at the end of the $\mathrm{ON}$ response is shown in Figure 3C. The time course of the cone response at a location close to the center of the stimulus was sustained with a characteristic overshoot at both stimulus ON and OFF as shown in Figure 3D (Attwell et al., 1982). The sustained-to-peak response amplitude ratio of the $\mathrm{ON}$ response was $0.62 \pm 0.06$, and the time to peak of the ON response was $127 \pm 12 \mathrm{msec}$. Rods were saturated with background illumination (see Materials and Methods), so this cone pattern defines the space-time input to bipolar and horizontal cells. Patterns emerging at more proximal

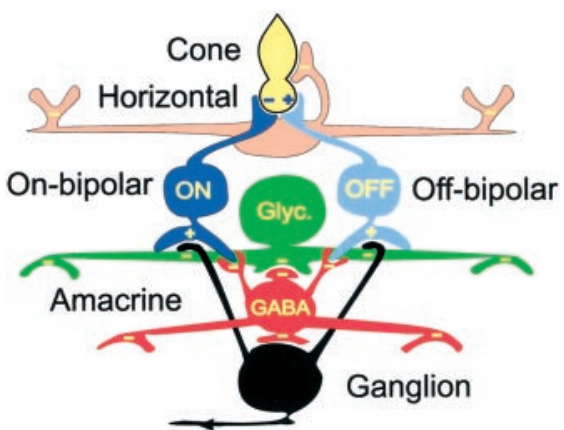

Figure 2. A schematic salamander retina shows some important cells and their connections to help the reader understand the Results section. Glyc, Glycine.

retinal layers differ from the cone pattern in space or time, as a consequence of further retinal processing.

\section{The activity pattern at the horizontal cell layer spreads and contracts over time}

Unlike the very narrow cone pattern, a spatially extensive and dynamically complex membrane potential activity pattern was evoked by the $300-\mu \mathrm{m}$-wide stimulus at the horizontal cell layer, as shown in Figure 4A. Just after light ON, activity originated at the site corresponding to the center of the stimulus location and spread laterally with an initial speed of $2.2 \pm 0.8 \mu \mathrm{m} / \mathrm{msec}$. This can be read from Figure $4 A$ as the convex shape of the initial response pattern. The spread of activity is probably mediated by coupling between horizontal cells (Kolb, 1977; Witkovsky et al., 1983; Kaneko and Stuart, 1984), because the unilateral spatial extent of the dendrites of the measured horizontal cells were $\leq 170 \mu \mathrm{m}$. The spatiotemporal properties of the activity pattern are determined by the cable properties and the coupling state of the horizontal cell syncytium. At $260 \pm 20 \mathrm{msec}$ after light $\mathrm{ON}$, activity began to contract in space (Fig. $4 C$ ) and reached a steady-state space constant of $370 \pm 117 \mu \mathrm{m}(n=9)$ with a steady-state-to-peak space constant ratio of $0.8 \pm 0.12(n=9)$. This contraction is most probably caused by feedback from horizontal cells to cones (Baylor et al., 1971; Attwell et al., 1983; Wu, 1991; Kamermans et al., 1996). The spread and contraction of activity expressed quantitatively by the time course of the space constant are shown in Figure 4B. The spatial distribution of the time-to-peak parameter is also consistent with the lateral diffusion of horizontal cell activity. The time to peak at central locations, receiving direct input from cones, was $214 \pm 57 \mathrm{msec}$ $(n=9)$. Moving laterally from the edge of the stimulus, the time-to-peak parameter increased with an initial rate of $0.13 \pm$ $0.07 \mathrm{msec} / \mu \mathrm{m}$. Like the activity at light $\mathrm{ON}$, activity at light OFF also spread laterally. At both stimulus onset and offset, the time course of the response at a central location (Fig. 4D, trace 3) was characteristically different from the response at a more lateral location (Fig. 4D, trace 4); the lateral response started later, was slower, and had smaller amplitude. Our findings during light $\mathrm{ON}$ are consistent with a simple model in which horizontal cells are coupled and feedback to the cones with a delay. As a result of this feedback the spatial representation of the stimulus at the horizontal cell layer becomes more compressed during the development of the ON response after the early spatial peak. In some measurements this simple delayed feedback model failed to predict the time course of the horizontal cell light response at light OFF; the OFF peak of the horizontal cell light response came 
A
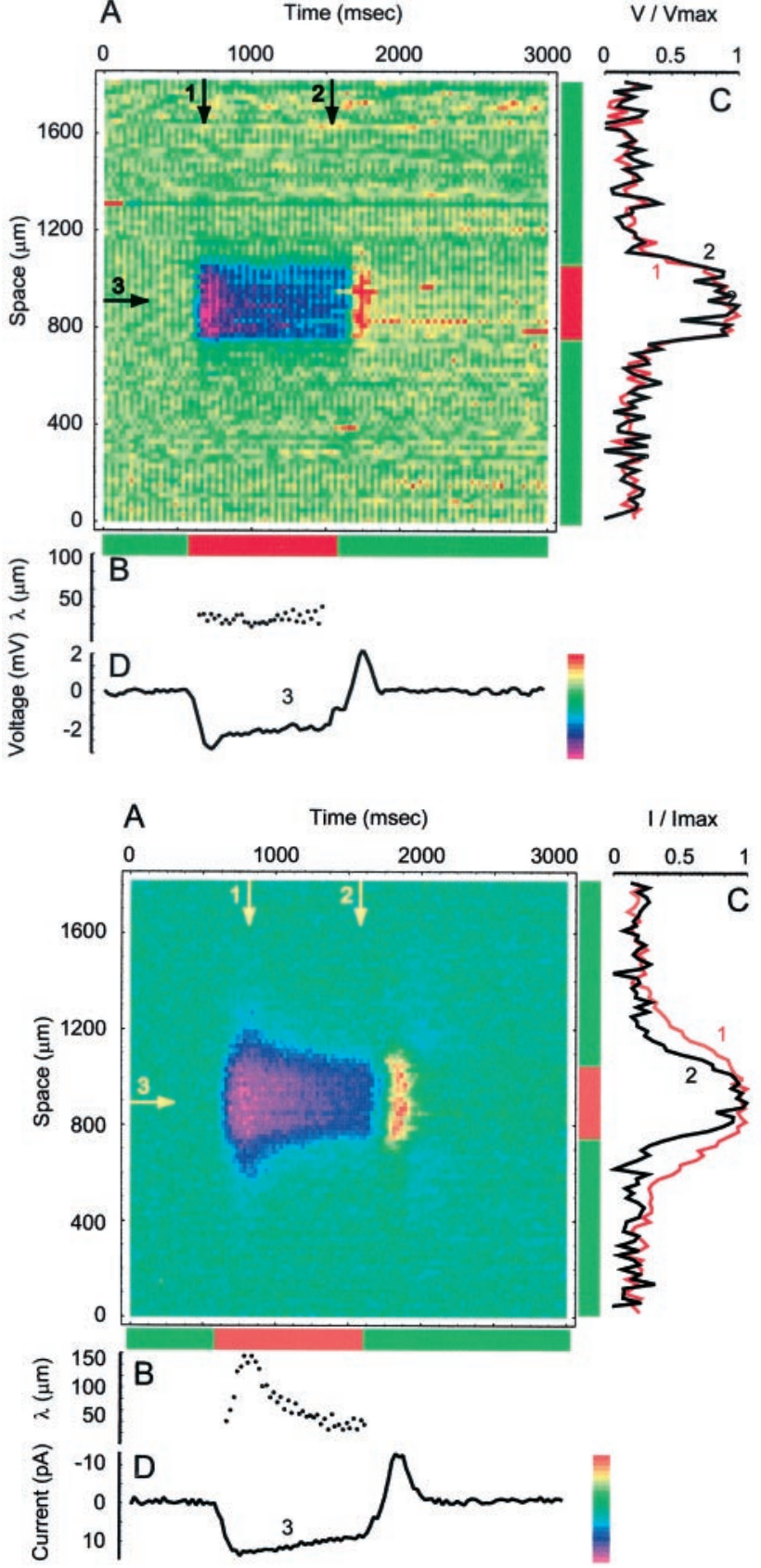

A
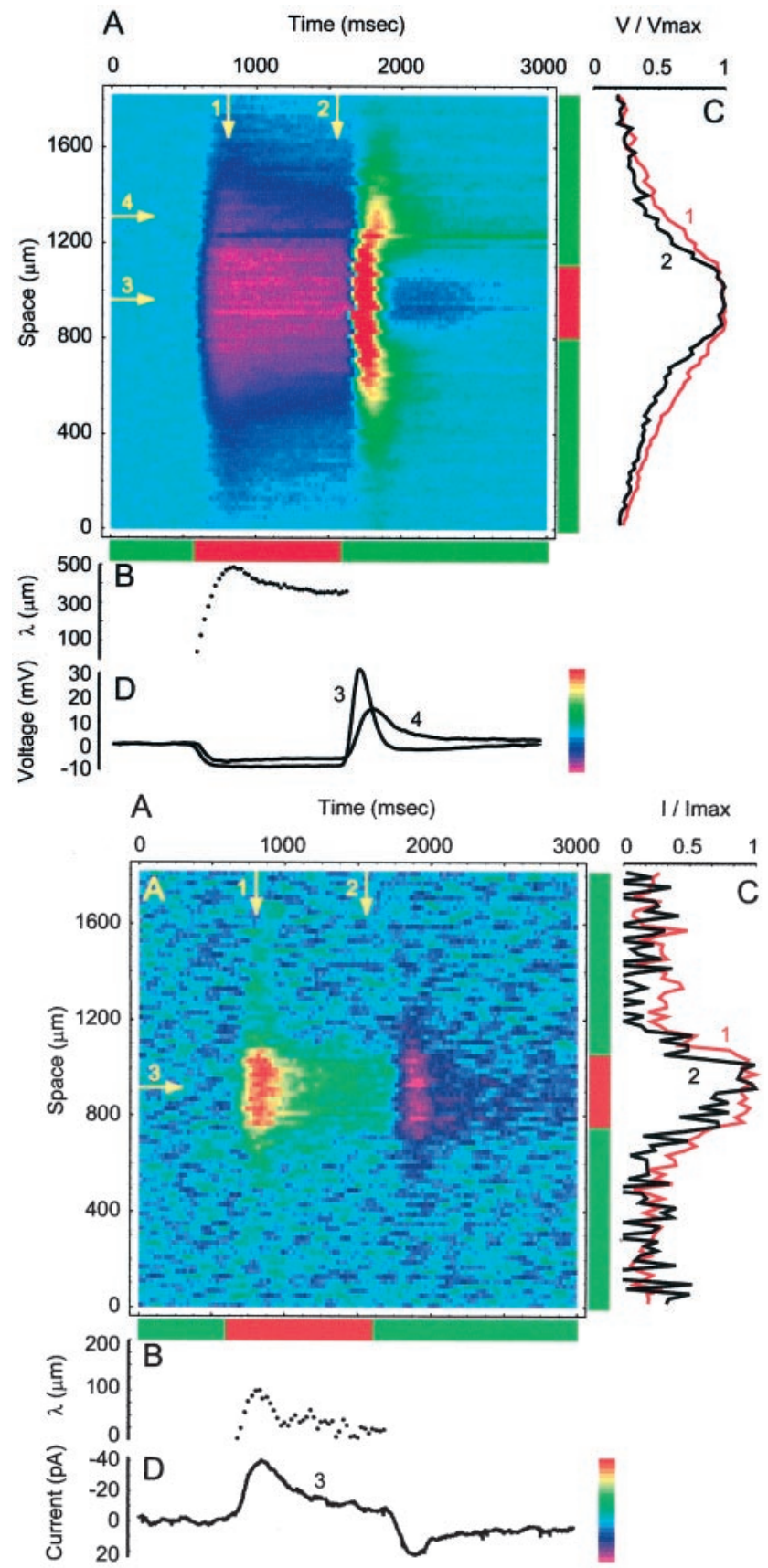

Figure 3. Top left. The space-time pattern of activity at the cone layer closely matches the stimulus in both space and time. $A$, Color-coded space-time plot. The $y$-axis represents the spatial locations of a row of 91 retinal cells separated by $20 \mu \mathrm{m}$ along a $1.82 \mathrm{~mm}$ retinal slice. The $x$-axis represents time binned in $25 \mathrm{msec}$ intervals. The stimulus is represented by the red bars. The horizontal red bar defines the timing (the stimulus is presented for 1 sec), and the vertical red bar defines the spatial extent and position of the stimulus. Each row represents the time course of the responses of each of 91 cells positioned at each location along the retinal slice. Each column represents the spatial distribution of activities of 91 cells along the retinal slice at a fixed time. The row marked by the horizontal arrow is shown in $D$, and columns marked by the vertical arrows are shown in $C$. The color code is shown at the bottom right corner of the figure. $B$, The time course of the space constant. $C$, The distribution of activities in space at the peak and at the end of the ON response, marked by vertical arrows 1 and 2 in $A$. D, The time course of the voltage response at a central location, marked by horizontal arrow 3 in $A$.

Figure 4. Top right. The space-time pattern of activity at the horizontal cell spreads and contracts over time. $A$, A color-coded space-time pattern of membrane voltage at the horizontal cell layer. The representation of the measurements in color-coded plots is explained in Figure 1 . The convexity indicates a spread of activity for the first $160 \mathrm{msec}$. $B$, The time course of the space constant. $C$, The distribution of activities in space at the peak and at the end of the ON response, marked by vertical arrows 1 and 2 in $A$. D, The time course of the voltage response at a central and a more lateral location, marked by horizontal arrows 3 and 4 in $A$.

Figure 5. Bottom left. The space-time pattern of activity at the OFF bipolar cell layer shows contraction. $A$, A color-coded space-time pattern of excitatory current at the OFF bipolar cell layer. The representation of the measurements in color-coded plots is explained in Figure 1 . $B$, The time course of the space constant. $C$, The distribution of activities in space at the peak and at the end of the ON response, marked by vertical arrows 1 and 2 in $A$. D, The time course of the current response at a central location, marked by horizontal arrow 3 in $A$.

Figure 6. Bottom right. The space-time pattern of activity at the $\mathrm{ON}$ bipolar cell layer shows contraction. $A$, A color-coded space-time pattern of excitatory current at the $\mathrm{ON}$ bipolar cell layer. The representation of the measurements in color-coded plots is explained in Figure $1 . B$, The time course of the space constant. $C$, The distribution of activities in space at the peak and at the end of the ON response, marked by vertical arrows 1 and 2 in $A$. D, The time course of the current response at a central location, marked by horizontal arrow 3 in $A$. 
before the cone OFF peak at the central location. Voltage-gated sodium channels in horizontal cells (Gilbertson et al., 1991) might explain this early OFF peak.

\section{Activity patterns at both $\mathrm{ON}$ and OFF bipolar cell layers also display contraction}

If the contraction of the activity pattern at the horizontal cell layer is caused by feedback to cones, bipolar cell layers receiving direct synaptic input from cones should also display contraction. To avoid the contribution of chloride-mediated postsynaptic inhibition at the bipolar cell soma and terminal (Lukasiewicz et al., 1994; Dong and Werblin, 1998; Maple and Wu, 1998; Roska et al., 1998 ) to the measured activity pattern at the bipolar cell layer, we voltage-clamped bipolar cells at the chloride reversal potential $\left(E_{\mathrm{Cl}}\right)$ of $-60 \mathrm{mV}$. As shown previously (Lukasiewicz et al., 1994; Roska et al., 1998) the contribution of chloride-mediated currents in salamander bipolar cells clamped at or near $E_{\mathrm{Cl}}$ is negligible; therefore the recorded currents at $E_{\mathrm{Cl}}$ should reflect only the excitatory input from cones.

\section{Activity pattern at the OFF bipolar cell layer}

A characteristic excitatory current pattern at the OFF bipolar cell layer is shown in Figure $5 A$. The convexity of the pattern shows that after light $\mathrm{ON}$ activity first spread to reach a maximum space constant of $150 \pm 31 \mu \mathrm{m}$ and then contracted (Fig. $5 B, C$ ) to a space constant of $46 \pm 18 \mu \mathrm{m}(n=5)$. The spread of currents is probably caused by the combination of coupling and finite dendritic trees. The time course of the response at a central location (Fig. 5D) had a time to peak of $168 \pm 26 \mathrm{msec}$ and a sustainedto-peak ratio of $0.62 \pm 0.12(n=5)$. The parameters of the membrane voltage pattern at the OFF bipolar layer (data not shown) were similar to the parameters of the excitatory current pattern (maximum space constant, $156 \pm 75 \mu \mathrm{m}$; space constant after contraction, $32 \pm 35 \mu \mathrm{m}$; time to peak, $183 \pm 21 \mathrm{msec}$; and sustained-to-peak ratio, $0.6 \pm 0.1 ; n=6$ ). This suggests that at the OFF bipolar soma direct inhibition does not significantly shape the space-time pattern under the stimulus conditions used in this study.

\section{Activity pattern at the ON bipolar cell layer}

A characteristic excitatory current pattern at the ON bipolar cell layer is shown in Figure $6 \mathrm{~A}$. After light $\mathrm{ON}$ activity first spread to reach a maximum space constant of $94 \pm 48 \mu \mathrm{m}$ and then contracted (Fig. $6 B, C)$ to a space constant of $30 \pm 21 \mu \mathrm{m}(n=$ 10). Although the early response was broader, the steady-state activity pattern in bipolar cells approximated the spatial dimension of the stimulus. The time to peak at the central location was $202 \pm 25 \mathrm{msec}(n=10)$. At light OFF a similar spread and contraction were measured. The membrane voltage pattern (Yang and $\mathrm{Wu}, 1991$ ) displayed a similar but broader spread and contraction; after light $\mathrm{ON}$ the maximum space constant was $254 \pm 58 \mu \mathrm{m}$, which then declined to $69 \pm 35 \mu \mathrm{m}(n=7)$. Two distinct groups of ON bipolar cell types could be separated on the basis of the sustained-to-peak ratio of the responses in the time domain (at a central location). The first group, termed "sustained," had a sustained-to-peak ratio of $0.65 \pm 0.11(n=6)$ that is very similar to the sustained-to-peak ratios of cone $(0.62 \pm$ $0.06)$ and OFF bipolar $(0.62 \pm 0.12)$ responses. The second group, termed "transient" (Fig. 6D), had a sustained-to-peak ratio of $0.20 \pm 0.09(n=11)$. The spatial parameters (maximum space constant and space constant after contraction) of the two groups were statistically nonseparable.

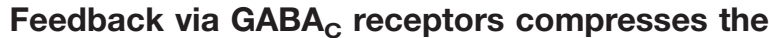 representation of the stimulus at bipolar terminals in both space and time}

As the activity patterns formed at the bipolar cell bodies enter the inner plexiform layer of the retina, they flow through key control points at the bipolar terminals. It was shown that local feedback from amacrine cells to bipolar terminals via $\mathrm{GABA}_{\mathrm{C}}$ receptors truncates the release of glutamate from bipolar cells in time (Zhang et al., 1997; Dong and Werblin, 1998). It is not known however whether this feedback acts only locally or whether it is mediated from a distance. If it were only local, blocking feedback should not change the spatial dimensions of the pattern of glutamate release from the bipolar terminals.

We estimated the space-time activity patterns of glutamate release from the ON bipolar terminals with and without blocking $\mathrm{GABA}_{\mathrm{C}}$ receptors. Release was monitored by measuring excitatory currents during light $\mathrm{ON}$ from narrow-field amacrine cells (selected to have processes of diameter $<200 \mu \mathrm{m}$ ) voltageclamped to the chloride reversal potential. These cells served as "glutamate electrodes."

We included $100 \mu \mathrm{M}$ bicuculline and $10 \mu \mathrm{M}$ strychnine in the control bath solution to block all inhibition to amacrine cells and bipolar cells via $\mathrm{GABA}_{\mathrm{A}}$ and glycine receptors, respectively. Under these pharmacological conditions the recorded amacrine cells received only excitatory currents (data not shown; $n=8$ ), so clamping these cells to the chloride reversal potential was an additional safety factor to isolate glutamate-gated synaptic currents. Most of the narrow-field amacrine cells receive excitatory input from both ON and OFF bipolar cells (Roska et al., 1998). To ensure that during light $\mathrm{ON}$ these amacrine cells received input only from ON bipolar cells, we applied $100 \mu \mathrm{M}$ APB, a specific blocker of the ON pathway (Slaughter and Miller, 1981), at the end of each experiment. In all amacrine cells used as glutamate electrodes, APB completely blocked the responses during light $\mathrm{ON}$, confirming that these cells received input exclusively from the ON bipolar system during light ON.

An approximation of the pattern of glutamate release at the ON bipolar terminal during light $\mathrm{ON}$ is shown in Figure $7 A$. In the presence of strychnine and bicuculline, when feedback via $\mathrm{GABA}_{\mathrm{C}}$ receptors was intact, the activity patterns at the $\mathrm{ON}$ bipolar terminal were compact in both space (Fig. 7A) and time (Fig. 7B). These patterns expanded in both space (Fig. 7C) and time (Fig. 7D) when GABA $_{C}$ receptors were blocked with $100 \mu \mathrm{M}$ picrotoxin. The maximum space constant (Fig. $7 E$ ), the duration (Fig. $7 F$ ), the time-to-peak (Fig. $7 G$ ), and the charge transfer (Fig. $7 H$ ) parameters all increased with the blocking of $\mathrm{GABA}_{\mathrm{C}}$ receptors in five patterns measured from different cells.

These experiments strongly suggest that amacrine cell feedback to bipolar terminals can mediate lateral inhibition and that the spatial effect of this feedback is to compress the activity at the bipolar terminals. We cannot determine the exact physiological magnitude of the spatial compression because to make the measured narrow-field amacrine cell sensitive only to glutamate our "control" solution contained bicuculline and strychnine. Under this pharmacological condition the feedback to bipolar cells is enhanced (Zhang et al., 1997; Roska et al., 1998).

\section{Amacrine cell activity patterns}

Amacrine cells constitute an extremely diverse population of inhibitory interneurons (Yang et al., 1991; MacNeil and Masland, 1998) making synapses with bipolar cells, ganglion cells, and other amacrine cells in the inner plexiform layer. Most amacrine 

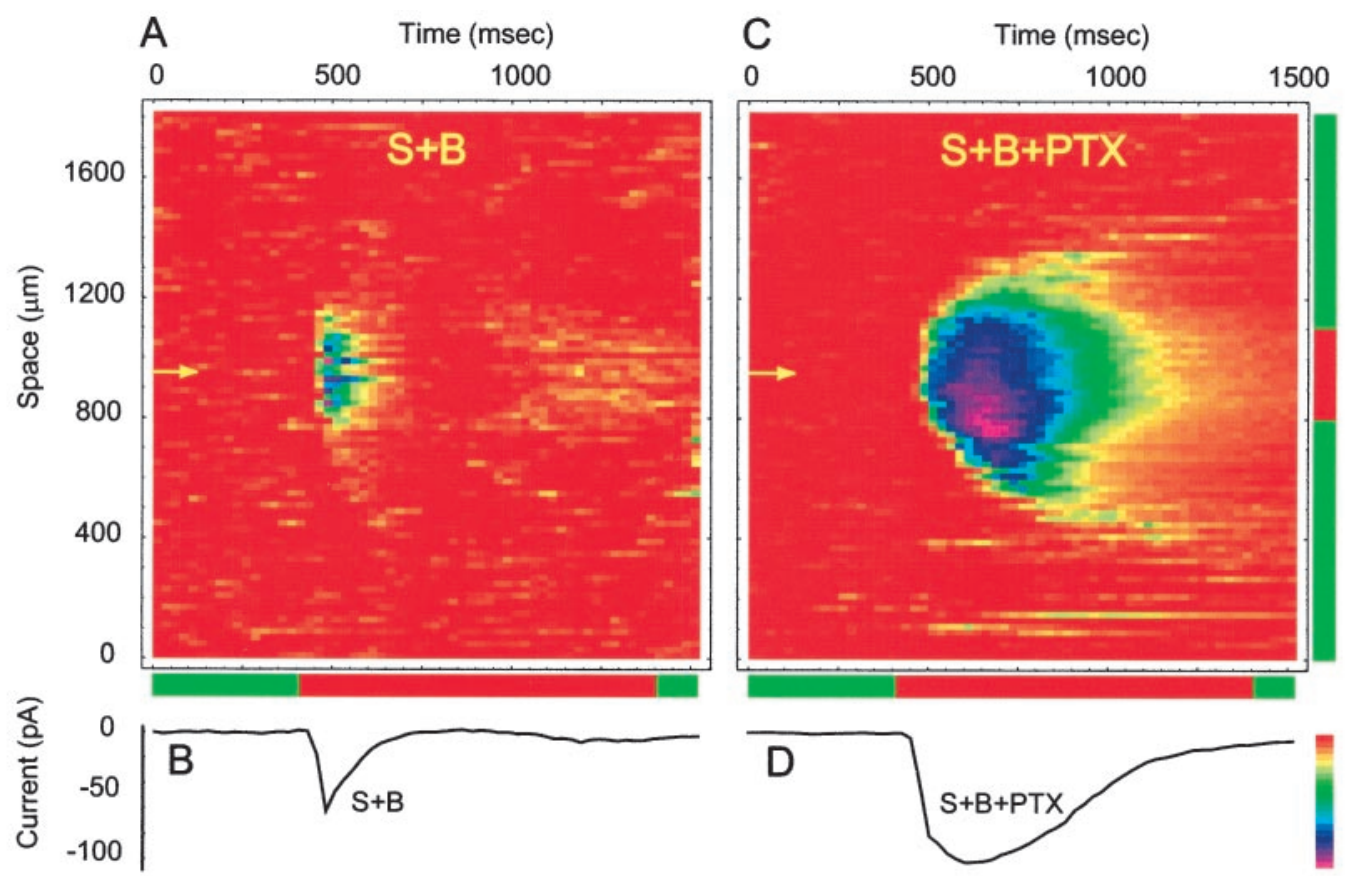

E1

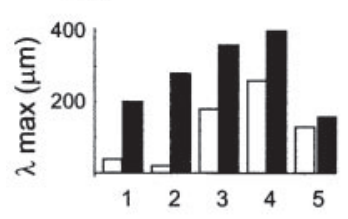

F1

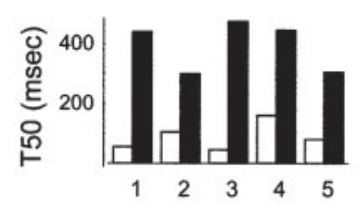

Strychnine + Bicuculline

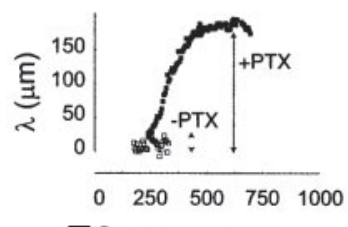

E2 Time (ms)

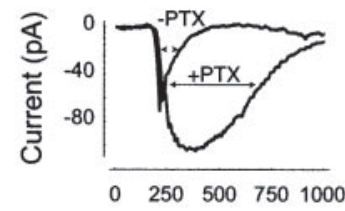

F2 Time (ms)

Figure 7. GABA $_{\mathrm{C}}$ blockade "blurs" the activity pattern at the $\mathrm{ON}$ bipolar terminal layer in both space and time. $A$, A color-coded space-time pattern of excitatory current at a narrow-field amacrine cell layer during light ON representing the activity pattern at the ON bipolar terminal layer. The representation of the measurements in color-coded plots is explained in Figure 1 . The bath solution contained $10 \mu \mathrm{M}$ strychnine $(S)$ and $100 \mu \mathrm{M}$ bicuculline $(B)$ to help isolate the excitatory synaptic currents. $B$, The time course of the response at a central location, marked by the horizontal arrow in $A$. $C$, The same measurement as in $A$ but with the $\mathrm{GABA}_{\mathrm{C}}$ receptors at bipolar terminals blocked by addition of $100 \mu \mathrm{M}$ picrotoxin $(P T X)$ into the bath solution. $D$, The time course of the response at a central location, marked by the horizontal arrow in $C$. E-H, The effect of GABA ${ }_{C}$ blockade on the activity pattern parameters at the ON bipolar terminal layer. The parameters were determined for five different experimental measurements of patterns of activities. E1-H1, The effect of $P T X$ on four pattern parameters during light ON. E1, Maximum space constant. F1, Duration (T50) at the central location. G1, Time $(T)$ to peak at the central location. H1, Charge transfer at the central location. The measured patterns are numbered on the $x$-axes. White bars represent pattern parameters measured when $\mathrm{GABA}_{\mathrm{C}}$ receptors were intact. Black bars represent pattern parameters measured when $\mathrm{GABA}_{\mathrm{C}}$ receptors were blocked by $P T X . E 2-H 2$, A visual guide indicating how these parameters were determined and what they mean. E2, The time course of the space constant in a pattern. The maximum space constants are shown by arrows. F2-H2, The response at the central location in the same pattern. Arrows represent $T 50$ in $F 2$ and time to peak in $G 2$. The charge transfer parameter is the integral of the current response during light ON, shown by the shaded area in $H 2$.

cells contain either the inhibitory neurotransmitter GABA or glycine or both (Marc et al., 1995). Moreover, recent experiments measuring the temporal correlation between ganglion cell spiking implied that amacrine cells might be electrically coupled to ganglion cells and in that context they would behave as excitatory cells (Brivanlou et al., 1998). We have measured the excitatory and inhibitory current patterns from 30 amacrine cells and found that the width of the excitatory input patterns closely correlated with the diameter of the amacrine cell processes (Fig. 8). The excitatory and inhibitory currents were isolated under control conditions, without pharmacological blockers, by voltage clamping the measured amacrine cell to $E_{\mathrm{Cl}}(-60 \mathrm{mV})$ and $E_{\mathrm{Glu}}(0$ $\mathrm{mV})$, respectively. The width of the inhibitory input patterns was uncorrelated with the diameter of the amacrine cell processes 


\section{Excitatory input pattern}
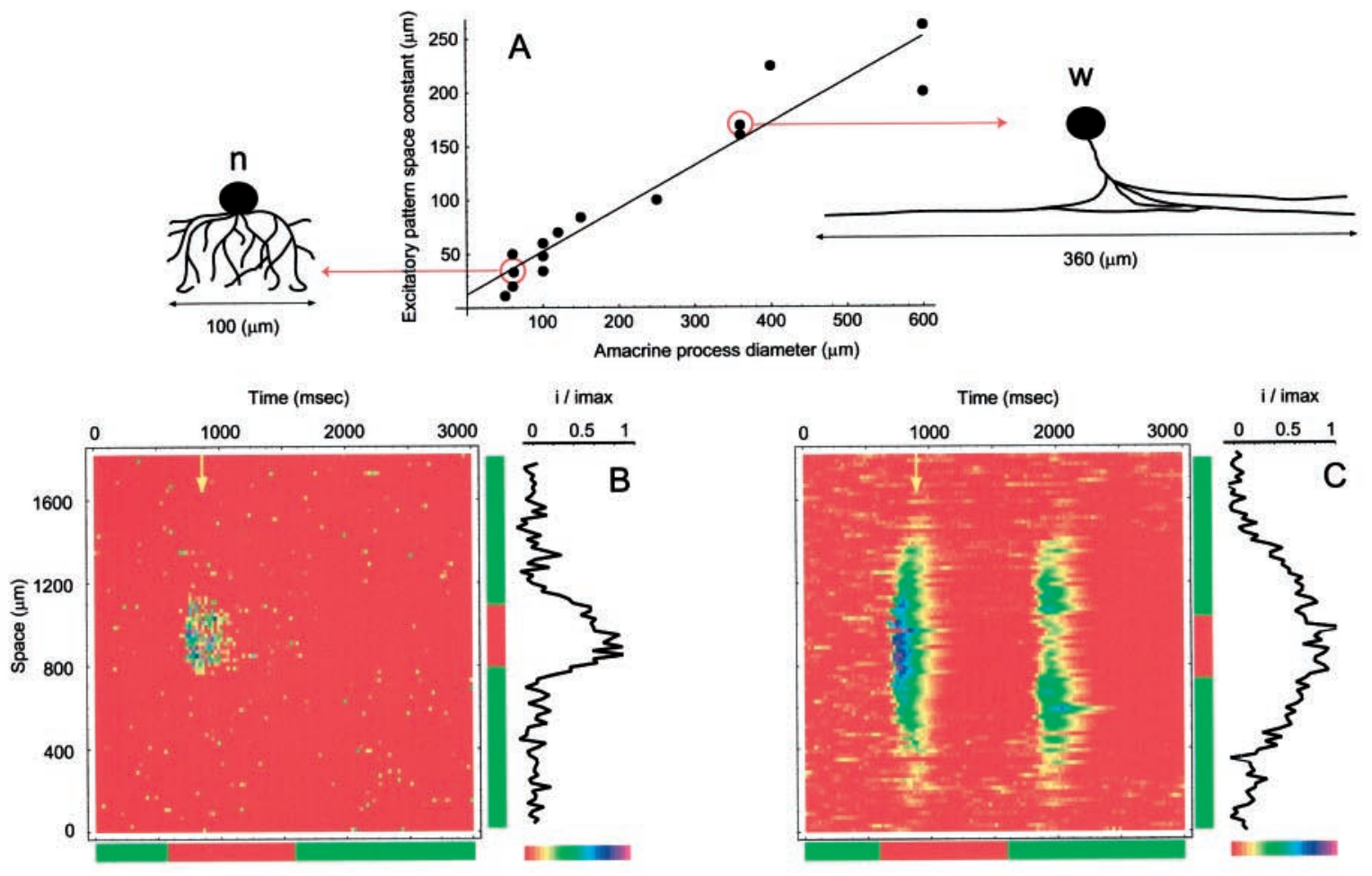

\section{Inhibitory input pattern}
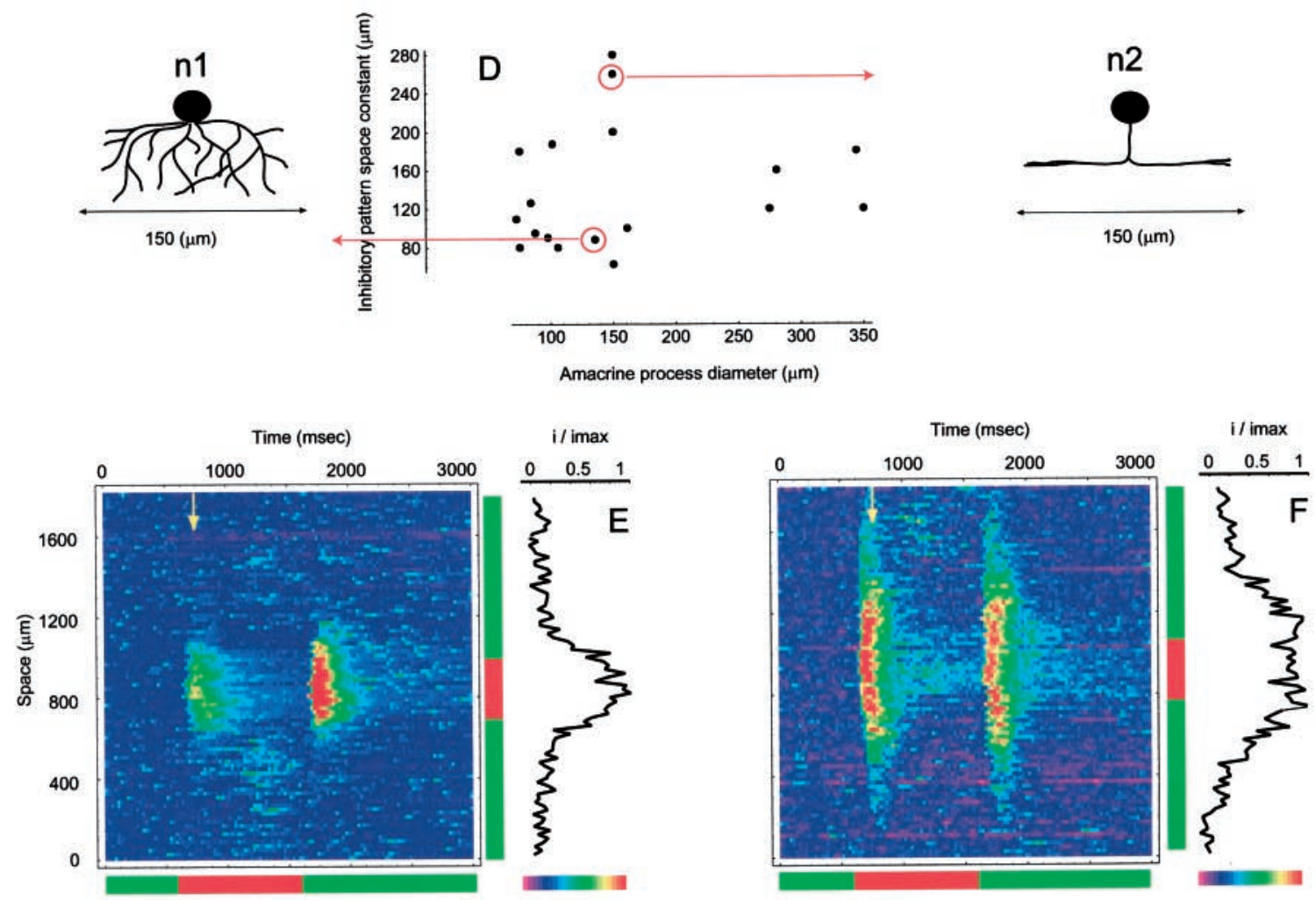

Figure 8. Excitatory and inhibitory input to amacrine cells. $A$, The width of the excitatory current pattern is a monotonically increasing function of the diameter of the amacrine cell processes. $B$, The excitatory current pattern to a narrow-field amacrine cell labeled $n$ in $A$ is shown. The representation of the measurements in color-coded plots is explained in Figure 1. $C$, The excitatory current pattern to a wide-field amacrine cell labeled $w$ in $A$ is shown. $D$, There is no simple relation between the width of the inhibitory current and the diameter of the amacrine cell processes. $E$, A narrow inhibitory current pattern to a narrow-field amacrine cell labeled $n 1$ in $D$ is shown. $F$, A wide inhibitory current pattern to another narrow-field amacrine cell labeled $n 2$ in $D$ is shown. 
(Fig. 8), implying that both narrow- and wide-field amacrine cells can receive either narrow- or wide-field inhibition.

\section{Feedforward inhibition via $\mathrm{GABA}_{\mathrm{A}}$ receptors compresses the spiking pattern at ganglion cells}

Ganglion cells receive excitatory input from bipolar cells and various forms of inhibitory input from amacrine cells (Lukasiewicz and Werblin, 1990; Han et al., 1997; Cook and McReynolds, 1998; Cook et al., 1998). Ganglion cells consist of four distinctly different cell classes according to the inhibitory and excitatory inputs they receive (Wunk and Werblin, 1979). The detailed differences between the space-time activity patterns will be published elsewhere. Here we focus on one ON-OFF ganglion cell class, which receives a dominant GABAergic inhibition. ONOFF ganglion cells were classified into this category if the inhibitory currents did not change or were increased by the addition of strychnine. One-third of the measured ON-OFF ganglion cells $(n=20)$ belonged to this class. Ganglion cell spikes were measured by the cell-attached patch technique (McLarnon, 1991; Diamond and Copenhagen, 1993) that leaves the composition of the interior of the measured cell intact. Comparison of Figure 9, $A$ and $C$, shows that blocking $\mathrm{GABA}_{\mathrm{A}}$ receptors increased both the duration and the spatial extent of the spiking pattern in this class of ganglion cells $(n=6)$. This "blurring" appears to be mediated by direct inhibition at ganglion cells. It is known that ganglion cells receive GABAergic inhibition via $\mathrm{GABA}_{\mathrm{A}}$ receptors (Lukasiewicz and Werblin, 1990; Cook and McReynolds, 1998; Lukasiewicz and Shields, 1998). The inhibitory current patterns $(n=4)$ mediated by GABAergic inhibition are shown in Figure $9 E$. However, the excitatory current pattern, a measure of bipolar input, to these ganglion cells does not widen by the application of bicuculline (data not shown; $n=5$ ). This suggests that the GABAergic effect is mediated at a site proximal to the bipolar terminals, i.e., at the ganglion cell dendrites.

\section{DISCUSSION}

Measuring the time course of the development of patterns representing a stimulus square provides a realistic, intuitive view of the neural images generated at each retinal level. These patterns represent the changes in time of the dimensions of the neural representations that would exist across a physical array of retinal cells covering $1.8 \mathrm{~mm}$. There are at least three distinct sites of lateral inhibition, each acting at a different receptor type, where the spatial representation of the stimulus is compressed in space. By comparing the space-time patterns at each level we have identified three new phenomena associated with the three different sites and a fourth one associated with the spatial distribution of inhibitory and excitatory input to amacrine cells. These observations are outlined below.

\section{All cells postsynaptic to cones have similar space-time patterns}

We showed that activity patterns at all cellular layers receiving direct input from cones have common space-time characteristics; after stimulus onset, the spatial representation expands for $\sim 160$ msec and then contracts (Fig. 10). The expansion has a wider lateral extent in horizontal than in bipolar cells probably because of greater coupling between neighboring horizontal cells. The contraction is probably mediated by inhibitory feedback from horizontal cells to cones. This notion is supported by the fact that excitatory current patterns in both $\mathrm{ON}$ and OFF bipolar cells, which reflect only the input from cones, display contraction. Kaneko and Tachibana (1986) proposed that $\mathrm{GABA}_{\mathrm{A}}$ receptors mediate feedback inhibition in the turtle. This notion was supported by $\mathrm{Wu}$ (1991) in the salamander. Several other papers proposed however that the feedback inhibition in salamander might not be mediated by ionotropic GABA receptors (Hare and Owen, 1996; Savchenko et al., 1997). Hare and Owen (1996) showed that the antagonistic surround in salamander bipolar cells could not be eliminated either by bicuculline or picrotoxin, implying that the receptor for the feedback inhibition is neither a $\mathrm{GABA}_{\mathrm{A}}$ nor $\mathrm{GABA}_{\mathrm{C}}$ type. Moreover it was shown in the goldfish that the feedback directly regulates $\mathrm{Ca}^{2+}$ concentration (Verweij et al., 1996) without changing the cone voltage. Our results that the cone voltage pattern does not display contraction and bicuculline does not block the spatial contraction in bipolar cells (result not shown) are consistent with the findings of Hare and Owen (1996) and Verweij et al. (1996). However our measurements could not exclude the contribution of an ionotropic GABAergic feedback (Wu, 1991) because our method of approximating the space-time patterns might have not been sensitive enough to measure small changes of space constants, especially in cones where the signal-to-noise ratio in our measurement was low. Moreover it is possible that small variations of voltage at the terminal caused by $\mathrm{GABA}_{\mathrm{A}}$ feedback could not be measured from the inner segment, the location of our patch electrode.

\section{$\mathrm{GABA}_{\mathrm{C}}$ feedback inhibition to bipolar terminals compresses the neural representation in space as well as in time}

Blocking $\mathrm{GABA}_{\mathrm{C}}$ receptors caused a massive spatial blur in the activity patterns at bipolar terminals (Fig. 7). GABA Geceptors (Feigenspan et al., 1993; Qian and Dowling, 1993; Lukasiewicz and Werblin, 1994; Lukasiewicz et al., 1994) are localized at bipolar terminals in the tiger salamander (Lukasiewicz and Werblin, 1994; Lukasiewicz et al., 1994) and were shown to truncate activity at bipolar terminals in time (Zhang et al., 1997; Dong and Werblin, 1998). Our results indicate that amacrine cell-mediated feedback inhibition to bipolar cells via $\mathrm{GABA}_{\mathrm{C}}$ receptors not only acts locally to truncate activity in time (Dong and Werblin, 1998) but also conveys inhibition laterally to compress the spatial representation of the stimulus across an array of bipolar terminals.

\section{GABA $_{A}$ feedforward inhibition compresses the neural representation in ganglion cells}

Blocking $\mathrm{GABA}_{\mathrm{A}}$-mediated inhibition with bicuculline blurs the spiking representation of the stimulus in both space and time in a subpopulation of ON-OFF ganglion cells (Fig. 9), which received a dominant postsynaptic GABAergic inhibition via $\mathrm{GABA}_{\mathrm{A}}$ receptors. One-third of the measured ON-OFF ganglion cells were classified into this subpopulation. The spatiotemporal blurring effect of $\mathrm{GABA}_{\mathrm{A}}$ blockage must be feedforward because bicuculline did not widen the excitatory input pattern (a measure of bipolar terminal activity) to these ganglion cells. This suggests that the spatial representation of the visual stimulus is sharpened by a feedforward amacrine cell class via $\mathrm{GABA}_{\mathrm{A}}$ receptors. Dong and Werblin (1998) measured voltage from ONOFF ganglion and found that in 3 out of 11 cells "bicuculline enhanced the voltage responses slightly." In our case in one-third of the ON-OFF ganglion cells bicuculline had a marked effect on the spiking pattern. The difference may depend on the measurement techniques; Dong and Werblin (1998) measured voltage in the whole-cell patch mode. In whole-cell patch mode we observed a rundown of inhibitory currents but not of excitatory currents. That means that in whole-cell patch mode the voltage measurement tends to emphasize the excitatory input but not the physi- 

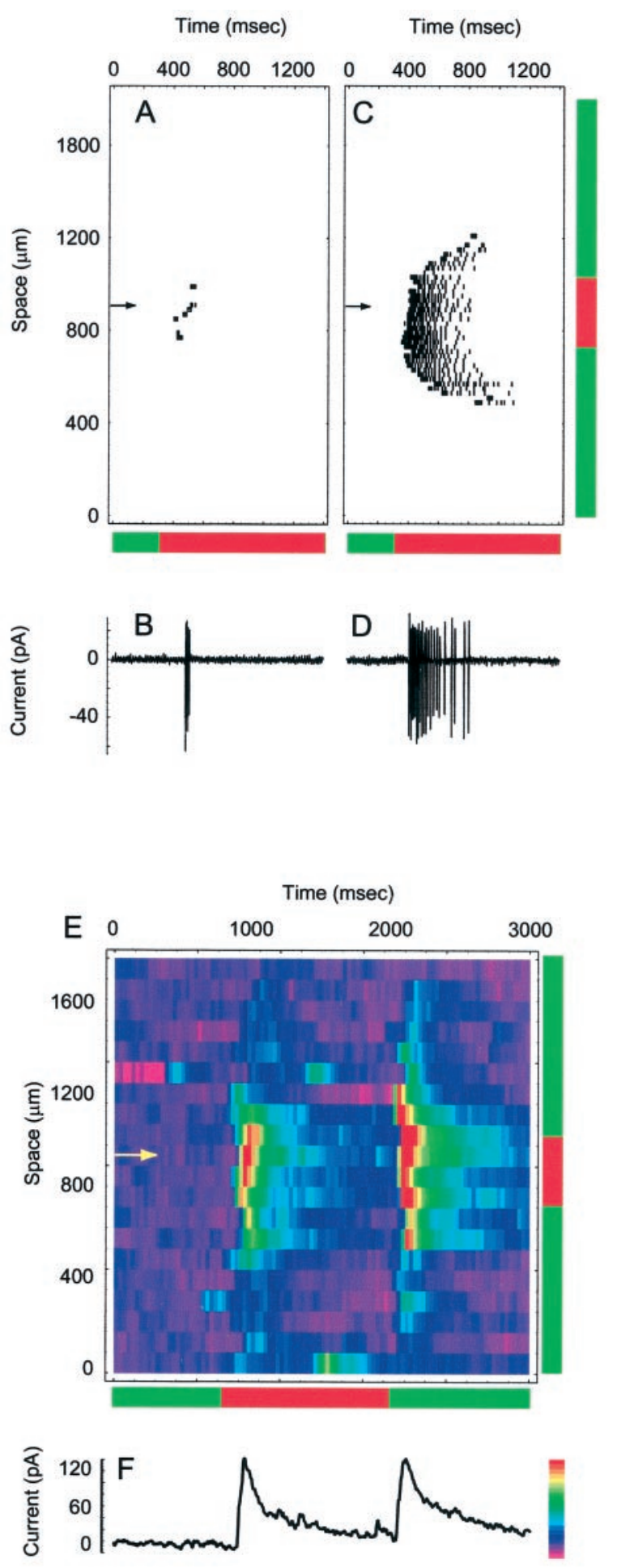

Figure 9. Amacrine cell feedforward via $\mathrm{GABA}_{\mathrm{A}}$ receptors compresses the spiking pattern at a subpopulation of ganglion cells in both space and time. $A$, A space-time pattern of spikes at a ganglion cell layer during light ON under control conditions. $B$, The time course of the response at a central location, marked by the horizontal arrow in $A$. $C$, A space-time pattern of spikes from the same ganglion cell layer during light $\mathrm{ON}$ in the presence of $100 \mu \mathrm{M}$ bicuculline. $D$, The time course of the response at a central location, marked by the horizontal arrow in $C$. E, An inhibitory current pattern at the ganglion cell layer in the presence of strychnine. The representation of the measurements in color-coded plots is explained in Figure 1. This pattern can be blocked by bicuculline. $F$, The time course of the inhibitory current response at a central location, marked by the horizontal arrow in $E$.

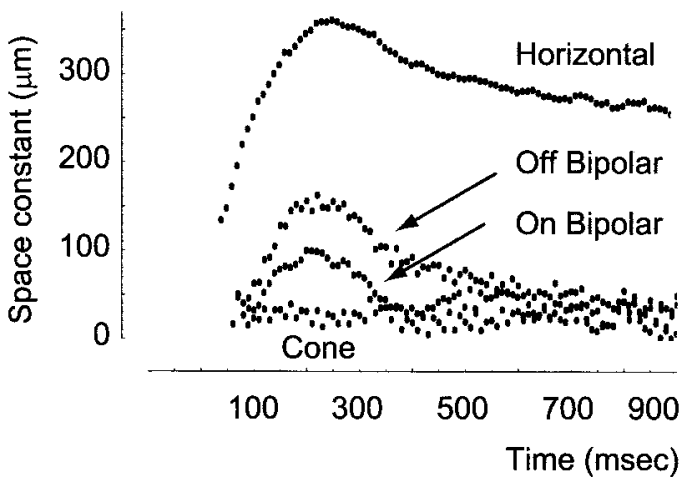

Figure 10. Comparison of the characteristic time courses of space constants in a horizontal cell, an ON bipolar cell, an OFF bipolar cell, and a cone. The shape of the space constant-time functions during light $\mathrm{ON}$ is similar in horizontal cells, OFF bipolar cells, and ON bipolar cells; the space constant increases for $\sim 160 \mathrm{msec}$ and then decreases and reaches a steady-state value. The space constant of the cone voltage pattern is not changed over time.

ological combination of inhibitory and excitatory inputs. We measured the spiking output in the ON cell patch mode, which allows us to measure the spiking output without decreasing the contribution of inhibition. Also the currents were measured with the perforated patch technique that prevents the rundown of the inhibitory currents.

\section{Relationship between spatial representation and process spread in amacrine cells}

Figure 8 shows that the width of the excitatory input pattern to amacrine cells correlates well with the width of the amacrine cell processes. This is consistent with the study of Bloomfield and Xin (1997) in rabbits showing that the receptive field size of amacrine cells correlates well with the diameter of their processes. A study of Cook and Werblin (1994) implied that wide-field amacrine cells receive excitatory input only through their proximal processes. Our results can be interpreted in two different ways. Either wide-field amacrine cells receive excitatory inputs along the entire length of their processes, or they receive excitatory input only through their proximal processes, but coupling to other amacrine cells increases their receptive field size. In either case the spatial representation of objects at the excitatory input of wide-field amacrine cells is much wider than is the object itself. The width of the inhibitory input to amacrine cells cannot be predicted by the extent of the amacrine cell processes. It is possible that a very precise, cell type-specific wiring exists between amacrine cells, but the rules for this connectivity cannot be inferred from these measurements.

\section{The use of pattern measurements to define retinal function}

To study the spatiotemporal dynamics at the different layers we used a technique first introduced by Ratliff and Hartline (1959) in Limulus and then used by others (Kirschfeld and Reichardt, 1964; Baumgartner, 1965) to define the spatial pattern generated by an edge because of lateral interactions in vertebrate vision. We extended the technique to study the development of responses over time. This technique allows us to view the spread and contraction of "neural activity" over time as each retinal array generates its representation of the stimulus. Neural activity patterns can be measured for excitatory (Figs. 5A, 6A) and inhibitory (Fig. $9 E$ ) currents. Alternatively cellular response can be mea- 
sured as changes in membrane potential (Figs. $3 A, 4 A$ ) or as spike activity (Fig. 9A,C). The measured patterns are only approximations for the true behavior of a given cell population because our reconstruction method assumes that every cell within a certain cell population has exactly the same space-time response properties, ignoring possible gradual changes in response properties with position across the retina. We cannot make any inferences about the density of the cell type, nor can we measure the correlation between activity among cells in the array (Brivanlou et al., 1998). Despite these limitations, the measured patterns provide valuable insights about the space-time dynamics of arrays of each cell type in the different cell layers and their imageprocessing roles in shaping the neural representation of the visual scene.

\section{The representation depends on background light intensity}

The receptive field organization changes significantly under different background illuminations (Kuffler, 1953; Barlow et al., 1957); the receptive field "contracts" with increasing background illumination. Similar dark-to-light changes are seen in retinal patterns. Jacobs and Werblin (1998) measured the extracellular pattern of spike activity evoked by a $300 \times 300 \mu \mathrm{m}$ square at the ganglion cell level. The patterns they recorded were significantly different from the patterns recorded in this study; the flashed square evoked a dynamically expanding pattern that extended well beyond the dimensions of the stimulus. Two conditions might explain the differences. First, Jacobs and Werblin (1998) used little or no background illumination; second, their stimulus was presented by a monitor generating stimulus intensities $2 \log$ units less bright than that in this study using a high-intensity lampLCD panel combination. Our background intensity $\left(13 \mu \mathrm{W} / \mathrm{mm}^{2}\right)$ was brighter than their stimulus intensity $\left(0.5-5 \mu \mathrm{W} / \mathrm{mm}^{2}\right)$. Under the conditions used by Jacobs and Werblin (1998) the rod system was probably active. By comparison, under our conditions the rods were saturated (Vu et al., 1997), and only the cone system was responsive. Therefore it seems likely that the differences of the recorded patterns are caused by the differences of rod response- versus cone response-dominated retinas. Indeed we have directly measured the spiking patterns from several ganglion cells in the whole-mount retina preparation with no background illumination and with the background illumination used in this study. We found that the spatial representation is significantly compressed by elevating background illumination (data not shown). The change in the functional architecture of the retina under different background illuminations remains to be explored.

\section{REFERENCES}

Attwell D, Werblin FS, Wilson M (1982) The properties of single cones isolated from the tiger salamander retina. $\mathrm{J}$ Physiol (Lond) 328:259-283.

Attwell D, Werblin FS, Wilson M, Wu SM (1983) A sign-reversing pathway from rods to double and single cones in the retina of the tiger salamander. J Physiol (Lond) 336:313-333.

Attwell D, Wilson M, Wu SM (1984) A quantitative analysis of interactions between photoreceptors in the salamander (Ambystoma) retina. J Physiol (Lond) 352:703-737.

Barlow HB (1953) Summation and inhibition in the frog's retina. J Physiol (Lond) 119:69-88.

Barlow HB, Fitzhugh R, Kuffler SW (1957) Change of organization in the receptive fields of the cat's retina during light adaptation. J Physiol (Lond) 137:338-354.

Baumgartner G (1965) Neuronale Mechanism des Kontrast- und Bewegungssehens. Berichte der deutchen Gesellschaft fur Ophthalmologie 66:111-125.
Baylor DA, Fuortes MG, O'Bryan PM (1971) Receptive fields of cones in the retina of the turtle. J Physiol (Lond) 214:265-294.

Bloomfield SA, Xin D (1997) A comparison of receptive-field and tracer-coupling size of amacrine and ganglion cells in the rabbit retina. Vis Neurosci 14:1153-1165.

Brivanlou IH, Warland DK, Meister M (1998) Mechanisms of concerted firing among retinal ganglion cells. Neuron 20:527-539.

Cook PB, McReynolds JS (1998) Lateral inhibition in the inner retina is important for spatial tuning of ganglion cells. Nat Neurosci 1:714-719.

Cook PB, Werblin FS (1994) Spike initiation and propagation in wide field transient amacrine cells of the salamander retina. J Neurosci 14:3852-3861.

Cook PB, Lukasiewicz PD, McReynolds JS (1998) Action potentials are required for the lateral transmission of glycinergic transient inhibition in the amphibian retina. J Neurosci 18:2301-2308.

Diamond JS, Copenhagen DR (1993) The contribution of NMDA and non-NMDA receptors to the light-evoked input-output characteristics of retinal ganglion cells. Neuron 11:725-738.

Diamond JS, Copenhagen DR (1995) The relationship between lightevoked synaptic excitation and spiking behavior of salamander retinal ganglion cells. J Physiol (Lond) 487:711-725.

Dong CJ, Werblin FS (1998) Temporal contrast enhancement via $\mathrm{GABA}_{\mathrm{C}}$ feedback at bipolar terminals in the tiger salamander retina. J Neurophysiol 79:2171-2180.

Feigenspan A, Wassle H, Bormann J (1993) Pharmacology of GABA receptor $\mathrm{Cl}-$ channels in rat retinal bipolar cells. Nature 361:159-162.

Gilbertson TA, Borges S, Wilson M (1991) The effects of glycine and GABA on isolated horizontal cells from the salamander retina. J Neurophysiol 66:2002-2013.

Han Y, Zhang J, Slaughter MM (1997) Partition of transient and sustained inhibitory glycinergic input to retinal ganglion cells. J Neurosci 17:3392-3400.

Hare WA, Owen WG (1996) Receptive field of the retinal bipolar cell: a pharmacological study in the tiger salamander. J Neurophysiol 76:2005-2019.

Horn R, Marty A (1988) Muscarinic activation of ionic currents measured by a new whole-cell recording method. J Gen Physiol 92:145-159.

Jacobs AL, Werblin FS (1998) Spatiotemporal patterns at the retinal output. J Neurophysiol 80:447-451.

Kamermans M, Haak J, Habraken JB, Spekreijse H (1996) The size of the horizontal cell receptive fields adapts to the stimulus in the light adapted goldfish retina. Vision Res 36:4105-4119.

Kaneko A (1970) Physiological and morphological identification of horizontal, bipolar and amacrine cells in goldfish retina. J Physiol (Lond) 207:623-633.

Kaneko A, Stuart AE (1984) Coupling between horizontal cells in the carp retina revealed by diffusion of Lucifer yellow. Neurosci Lett 47:1-7.

Kaneko A, Tachibana M (1986) Effects of gamma-aminobutyric acid on isolated cone photoreceptors of the turtle retina. J Physiol (Lond) 373:443-461.

Kirschfeld K, Reichardt W (1964) Die Verarbeitung stationarer optischer Nadhrichten im Komplexauge von Limulus. Kybernetik 2:43-61.

Kolb H (1977) The organization of the outer plexiform layer in the retina of the cat: electron microscopic observations. J Neurocytol 6:131-153.

Kuffler SW (1953) Discharge patterns and functional organization of mammalian retina. J Neurophysiol 16:37-68.

Lukasiewicz PD, Shields CR (1998) Different combinations of GABA and $\mathrm{GABA}_{\mathrm{C}}$ receptors confer distinct temporal properties to retinal synaptic responses. J Neurophysiol 79:3157-3167.

Lukasiewicz PD, Werblin FS (1990) The spatial distribution of excitatory and inhibitory inputs to ganglion cell dendrites in the tiger salamander retina. J Neurosci 10:210-221.

Lukasiewicz PD, Werblin FS (1994) A novel GABA receptor modulates synaptic transmission from bipolar to ganglion and amacrine cells in the tiger salamander retina. J Neurosci 14:1213-1223.

Lukasiewicz PD, Maple BR, Werblin FS (1994) A novel GABA receptor on bipolar cell terminals in the tiger salamander retina. $\mathrm{J}$ Neurosci 14:1202-1212.

MacNeil MA, Masland RH (1998) Extreme diversity among amacrine cells: implications for function. Neuron 20:971-982. 
Maple BR, Wu SM (1998) Glycinergic synaptic inputs to bipolar cells in the salamander retina. J Physiol (Lond) 506:731-744.

Marc RE, Murry RF, Basinger SF (1995) Pattern recognition of amino acid signatures in retinal neurons. J Neurosci 15:5106-5129.

McLarnon JG (1991) The recording of action potential currents as an assessment for drug actions on excitable cells. J Pharmacol Methods 26:105-111.

Qian H, Dowling JE (1993) Novel GABA responses from rod-driven retinal horizontal cells. Nature 361:162-164.

Rae J, Cooper K, Gates P, Watsky M (1991) Low access resistance perforated patch recordings using amphotericin B. J Neurosci Methods 37:15-26.

Ratliff F, Hartline HK (1959) The response of the Limulus optic nerve fibers to patterns of illumination on the receptor mosaic. J Gen Physiol 42:1241-1255.

Roska B, Nemeth E, Werblin FS (1998) Response to change is facilitated by a three-neuron disinhibitory pathway in the tiger salamander retina. J Neurosci 18:3451-3459.

Savchenko A, Barnes S, Kramer RH (1997) Cyclic-nucleotide-gated channels mediate synaptic feedback by nitric oxide. Nature 390:694-698.

Slaughter MM, Miller RF (1981) 2-Amino-4-phosphonobutyric acid: a new pharmacological tool for retina research. Science 211:182-185.

Verweij J, Kamermans M, Spekreijse H (1996) Horizontal cells feed back to cones by shifting the cone calcium-current activation range. Vision Res 36:3943-3953.

Vu TQ, McCarthy ST, Owen WG (1997) Linear transduction of natural stimuli by dark-adapted and light-adapted rods of the salamander, Ambystoma tigrinum. J Physiol (Lond) 505:193-204.

Werblin FS (1972) Lateral interactions at inner plexiform layer of vertebrate retina: antagonistic responses to change. Science 175:1008-1010.

Werblin FS (1978) Transmission along and between rods in the tiger salamander retina. J Physiol (Lond) 280:449-470.

Werblin FS, Dowling JE (1969) Organization of the retina of the mudpuppy, Necturus maculosus. II. Intracellular recording. J Neurophysiol 32:339-355.

Witkovsky P, Owen WG, Woodworth M (1983) Gap junctions among the perikarya, dendrites, and axon terminals of the luminosity-type horizontal cell of the turtle retina. J Comp Neurol 216:359-368.

Wu SM (1991) Input-output relations of the feedback synapse between horizontal cells and cones in the tiger salamander retina. J Neurophysiol 65:1197-1206.

Wunk DF, Werblin FS (1979) Synaptic inputs to the ganglion cells in the tiger salamander retina. J Gen Physiol 73:265-286.

Yang CY, Lukasiewicz P, Maguire G, Werblin FS, Yazulla S (1991) Amacrine cells in the tiger salamander retina: morphology, physiology, and neurotransmitter identification. J Comp Neurol 312:19-32.

Yang XL, Wu SM (1991) Feedforward lateral inhibition in retinal bipolar cells: input-output relation of the horizontal cell-depolarizing bipolar cell synapse. Proc Natl Acad Sci USA 88:3310-3313.

Zhang J, Jung CS, Slaughter MM (1997) Serial inhibitory synapses in retina. Vis Neurosci 14:553-563. 